\title{
Validity of flexicurve for the assessment of spinal flexibility in asymptomatic individuals
}

\author{
Validade do flexicurva na avaliação da flexibilidade da \\ coluna vertebral em indivíduos assintomáticos
}

\section{Validez del flexicurve en la evaluación de la flexibilidad de la columna vertebral en individuos asimomáticos}

\begin{abstract}
Marja Bochehin do Valle ${ }^{[a]}$, Vinícius Hoffmann Dutra ${ }^{[a]}$, Cláudia Tarragô Candotti $\mathbb{C}^{[a]}$, Juliana Adami Sedrez $\mathbb{\circledR}^{[a]}$, Edgar Santiago Wagner Neto $\mathbb{i}^{[a, b]}$, Jefferson Fagundes Loss $₫[a] *$
\end{abstract}

[a] Universidade Federal do Rio Grande do Sul (UFRGS), Porto Alegre, RS, Brazil

[b] Escola de Educação Profissional (Enrad), São Leopoldo, RS, Brazil

\section{Abstract}

Introduction: Spine problems are common, and assessment of spine flexibility provides relevant information; however, alternative evaluation methods need to be validated. Objective: To evaluate the concurrent validity of the Flexicurve using 3D videogrammetry as a reference value to assess spinal flexion and extension in the lumbar and thoracic regions. Method: The consecutive sample consisted of 39 individuals aged between 18 and 50 years. Two consecutive evaluations were performed by the same rater on the same day and at the same location: (1) Flexicurve and (2) 3D videogrammetry. The assessments were performed with the spine in the neutral position, followed by maximum flexion and extension. The range of motion (ROM) in the maximum flexion and extension positions was calculated in MATLAB ${ }^{\circledR}$ and defined as the difference between the maximum flexion or extension angle and that of the neutral position. Statistical analyses used were the Pearson Product-Moment Correlation coefficient, RMS error and Bland-Altman plot $(\alpha<0.05)$. Results: The ROM between instruments

\footnotetext{
* MBV: Doctoral student, e-mail: MarjaBV@hotmail.com VHD: BS, e-mail: vinidutra@gmail.com CTC: PhD, e-mail: claudia.candotti@ufrgs.br JAS: PhD, e-mail: julianasedrez@gmail.com ESWN: Doctoral student, e-mail: edgar.swagner@gmail.com JFL: PhD, e-mail: jefferson.loss@ufrgs.br
} 
was similar, with high correlations for thoracic flexion $(\mathrm{r}=0.751)$, extension $(\mathrm{r}=0.814)$ and lumbar flexion $(r=0.853)$, and RMS errors under $8^{\circ}$. The correlation for lumbar extension was moderate $(r=0.613)$ and the RMS error was more than $10^{\circ}$. The limits of agreement varied between $\pm 10^{\circ}$ and $\pm 21^{\circ}$. Conclusion: The Flexicurve is valid for assessing maximum flexion and extension of the thoracic spine, and maximum flexion of the lumbar spine. We suggest caution in evaluating the maximum extension of the lumbar spine.

Keywords: Validation Studies. Measurement Equipment. Pliability. Spine.

\section{Resumo}

Introdução: Problemas na coluna vertebral são frequentes, sendo a avaliação da flexibilidade uma informação relevante a ser considerada pelo profissional. Métodos alternativos para realizar avaliação da flexibilidade da coluna carecem de validação. Objetivo: Avaliar a validade concorrente do Flexicurva utilizando a videogrametria 3D como medida de referência, para a avaliação da flexibilidade em flexão e extensão da coluna vertebral torácica e lombar. Método: A amostra consecutiva contou com 39 indivíduos com idades entre 18 e 50 anos. Duas avaliações consecutivas foram realizadas pelo mesmo avaliador no mesmo dia e local: (1) Flexicurva e (2) videogrametria 3D. As avaliações foram realizadas com a coluna na posição neutra, seguida das posições de flexão e extensão máximas. A ADM nas posições de flexão e extensão máximas foram calculadas no $M A T L A B^{\circledR}$, sendo definida como a diferença entre os ângulos máximos de flexão ou extensão e a angulação da posição neutra. Na análise estatística utilizou-se: Teste de Correlação Produto-Momento de Pearson, Erro RMS e Análise de Bland-Altman. $(\alpha<0,05)$. Resultados: Os valores de ADM entre os instrumentos foram similares, com correlações altas para a flexão torácica $(r=0,751)$, extensão torácica $(r=0,814)$ e para flexão lombar ( $r=0,853)$, com erros RMS inferiores a $8^{\circ}$. Para a extensão lombar a correlação foi moderada $(r=0,613)$, com erro RMS superior a $10^{\circ}$. Limites de concordância variaram entre $\pm 10^{\circ}$ e $\pm 21^{\circ}$. Conclusão: $O$ Flexicurva mostrou-se válido para avaliar o movimento flexão máxima e extensão máxima da coluna torácica, e flexão máxima da coluna lombar. Sugerimos cautela na avaliação da extensão máxima da coluna lombar.

Palavras-chave: Estudos de Validação. Equipamentos de Medição. Maleabilidade. Coluna Vertebral.

\section{Resumen}

Introducción: Los problemas en la columna vertebral son frecuentes, siendo la evaluación de la flexibilidad de la columna vertebral una información relevante a ser considerada por el profesional. Los métodos alternativos para realizar la evaluación de la flexibilidad de la columna necesitan validación. Objetivo: Evaluar la validez concurrente del Flexicurva utilizando la videogrametría 3D como medida de referencia para evaluar la flexión y extensión de la columna en las regiones lumbar y torácica. Método: La muestra consecutiva consistió en 39 individuos de edades comprendidas entre 18 y 50 años. El mismo evaluador realizó dos evaluaciones consecutivas en el mismo día y local: (1) Flexicurve (2) Videogrametría 3D. Las evaluaciones se realizaron con la columna en posición neutral seguida de la máxima flexión y extensión. El RDM en la posición máxima de flexión y extensión se calculó en MATLAB®, la flexión máxima y la extensión se definieron como la diferencia entre el ángulo de la posición con respecto al punto neutro. Los análisis estadísticos consistieron en la prueba de correlación de producto-momento de Pearson, error de RMS y los análisis de Bland-Altman $(\alpha<0,05)$. Resultados: Los valores de RDM entre instrumentos fueron similares, con altas correlaciones para flexión torácica ( $r=0.751)$, extensión torácica $(r=0.814)$ y flexión lumbar $(r=0.853)$, y errores RMS por debajo de $8^{\circ}$. Para la extensión lumbar, se moderó la correlación $(r=0,613)$ y el error RMS fue superior a $10^{\circ}$. Los límites de concordancia variaron entre $\pm 10^{\circ}$ y $\pm 21^{\circ}$. Conclusión: El Flexicurva se mostró válido para evaluar la flexión máxima y la extensión máxima de la columna torácica, y la flexión máxima de la columna lumbar. Sugerimos precaución al evaluar la extensión máxima de la columna lumbar.

Palabras clave: Estudios de Validación. Equipos de Medición. Docilidad. Columna Vertebral. 


\section{Introduction}

Spinal mobility exhibits distinct characteristics depending on the anatomical region, due to morphological differences in the length and angulation of spinous processes and the volume of vertebral bodies [1]. Adequate spinal flexibility is important to maintain functional capacity [2-6] and is recommended for pain treatment [7-8]. Given that evidence-based clinical guidelines have suggested assessing spinal range of motion in patients with low back pain [9], measuring spinal flexibility should be part of routine assessments. One possibility is measuring spinal range of motion (ROM) in the sagittal plane, that is, the maximum flexion and extension of each region.

One ROM assessment option is the use of radiographs to measure spinal curvature angles in the neutral position or at maximum flexion and extension. However, X-rays pose a health risk to patients from the exposure to ionizing radiation, and frequent use is not recommended for clinical follow-up $[10,11]$. In a recent systematic review, Valle, Schmit, Sedrez and Candotti [12] investigated alternative methods to assess spinal flexibility. However, only the tape measure in the modified Schoeber test, 3D videogrammetry and the Flexicurve exhibited scientific evidence supporting their repeatability and/or reproducibility.

The 3D videogrammetry technique, which uses a system of cameras to determine kinematic movement parameters, is the gold standard for assessing maximum ROM [13-15]. However, the high cost of these systems makes the method clinically unfeasible [16], restricting it to the field of research.

The Flexicurve, a low-cost portable flexible rubber ruler, can be used in diagnosis and evolutionary indicators for treatment, and has the advantage of providing a graphic representation of the curvatures assessed. However, despite the adequate intraand interrater reproducibility obtained $[17,18]$, this instrument is used only to assess ROM in the lumbar region, restricting its application, since it has not been tested in the thoracic spine. Moreover, a recent systematic review found only two studies that tested the validity of the Flexicurve, both with low methodological quality [12]. Thus, the aim of this study was to evaluate the concurrent validity of the Flexicurve using 3D videogrammetry as reference to assess thoracic and lumbar spine flexion and extension.

\section{Methods}

\section{Sample}

Sample size was calculated using G*Power 3.1 software, based on bivariate correlation tests for parametric data, adopting a statistical power of $80 \%$, error probability of 5\% and null hypothesis of 0.3 (that is, any correlation less than 0.3 is considered clinically unacceptable) in order to obtain a minimum correlation of 0.65 , which resulted in an estimated $n$ of 39 individuals [19].

The consecutive sample consisted of healthy individuals of both sexes, aged between 18 and 50 years. Individuals with recurring low back pain in the month before assessment, limb length discrepancy, previous spinal surgery, known orthopedic disorders of the spine and severe abdominal scarring were excluded.

\section{Data Collection}

The data were collected at two consecutive stages, performed by the same rater on the same day and location: assessment with the Flexicurve and (2) 3D videogrammetry. The interval between assessments was around $10 \mathrm{~min}$, sufficient time to place the reflexive markers used in videogrammetry. Participants wore suitable clothing, such as a bikini, swimming trunks, top and Bermuda shorts, in order to expose the back, and were barefoot with their hair tied back, when necessary.

\section{Flexicurve Assessment}

First, the anatomical points of reference were palpated and marked with a dermographic pencil. These included the spinous processes (SP) of vertebra $\mathrm{C} 7, \mathrm{~T} 1, \mathrm{~T} 6, \mathrm{~T} 12, \mathrm{~L} 4$ and $\mathrm{S} 2$. The points were selected according to the literature [20]. Assessments were initially conducted with the spine in the neutral position, followed by maximum flexion and extension positions.

With the individuals standing in a neutral position, shoulders and elbows flexed at $90^{\circ}$ and leaning against the wall, the Flexicurve was shaped to their back and the points that represented the SPs marked on the skin were identified on the Flexicurve [20]. To assess the spine in flexion, individuals remained seated on a backless chair and were 
instructed to keep their ischia (lower and back part of the hip bone) on the seat and perform maximum spinal flexion during expiration (Figure 1a). In order to assess spinal extension, individuals remained in the decubitus position on a gurney and

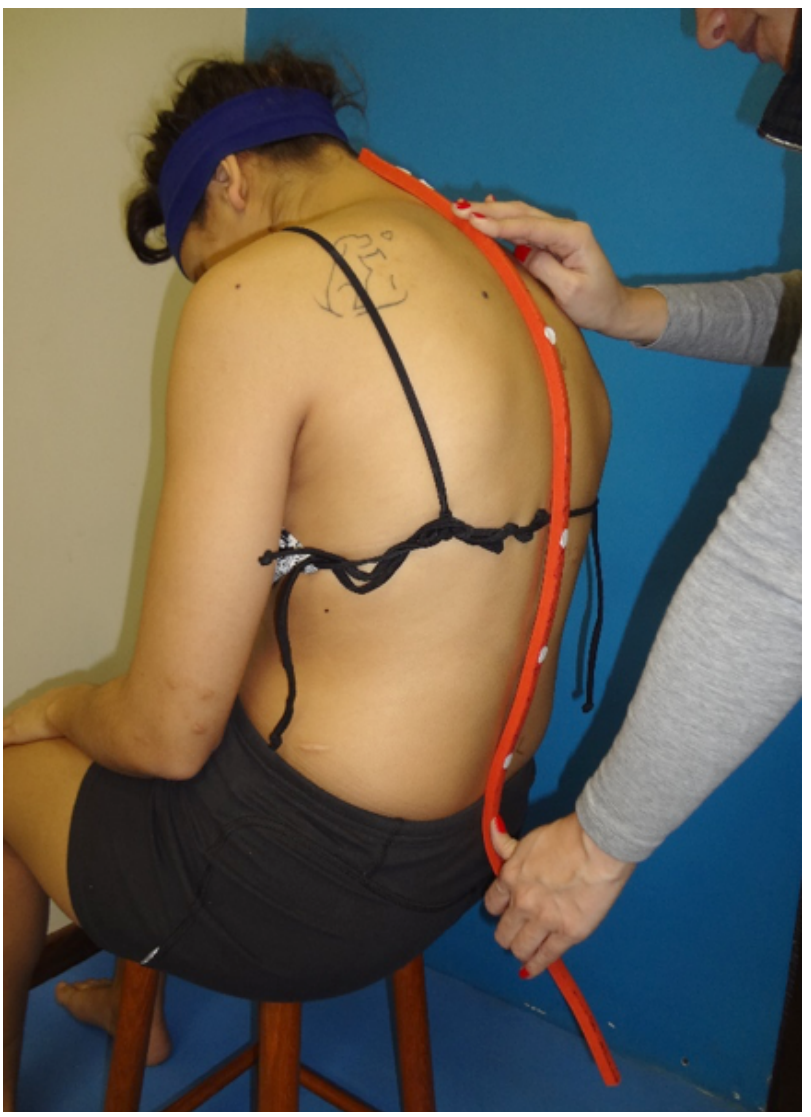

(a) were instructed to keep their hands on the gurney aligned with their shoulders, elbows bent, anterior superior iliac spine (ASIS), legs and feet supported by the gurney while extending their elbows during expiration (Figure 1b).

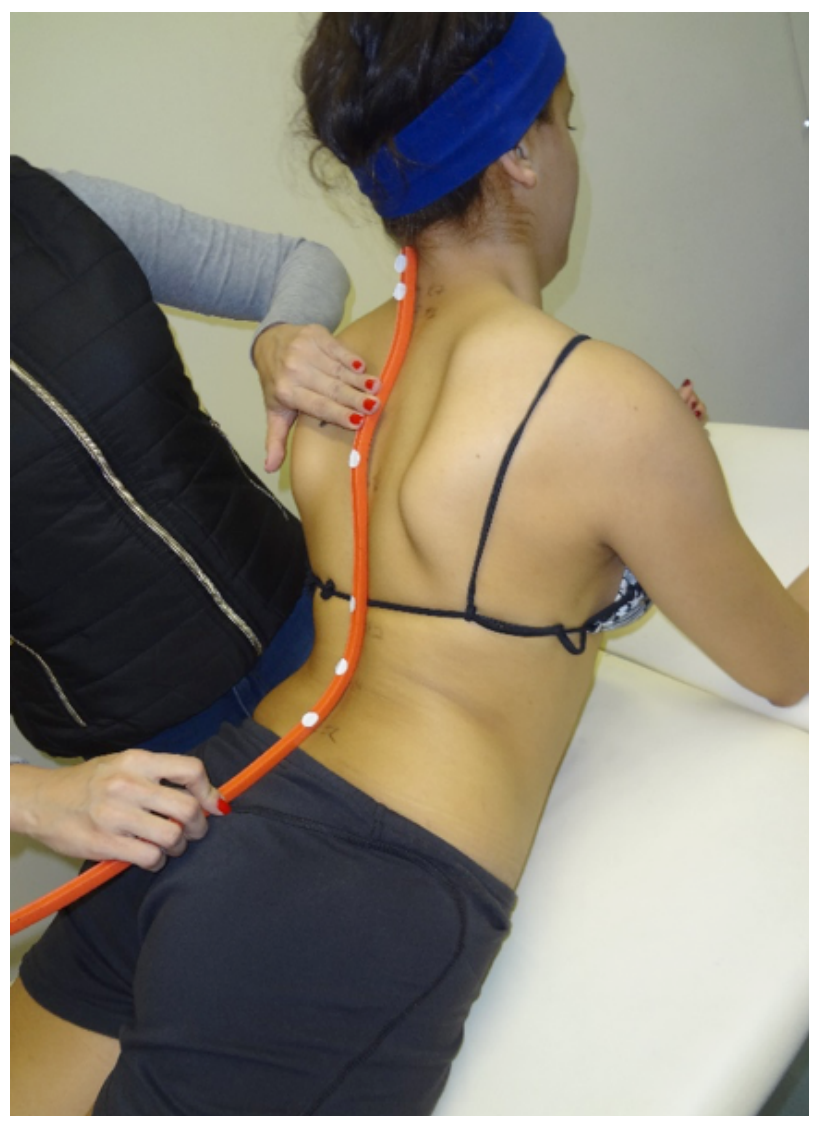

(b)

Figure 1 - Assessment of the spine in flexion (a) and extension (b).

Three repetitions were conducted to assess flexion and extension, two for familiarization purposes and the third to shape the Flexicurve. In all three situations (neutral, and maximum flexion and extension), the Flexicurve was carefully

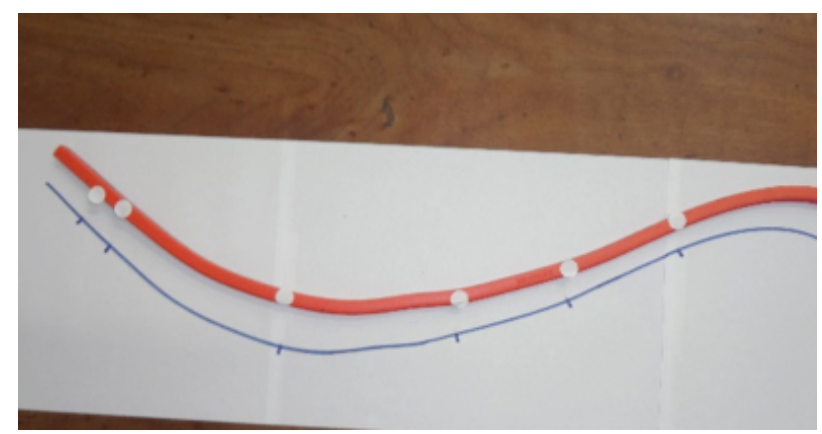

(a) removed from the back and placed on a sheet of paper, with its outline traced and the SPs identified (Figure 2). A digital photograph of the drawn curve was taken with a Nikon COOLPIX AW130, with the lens placed parallel to the paper.

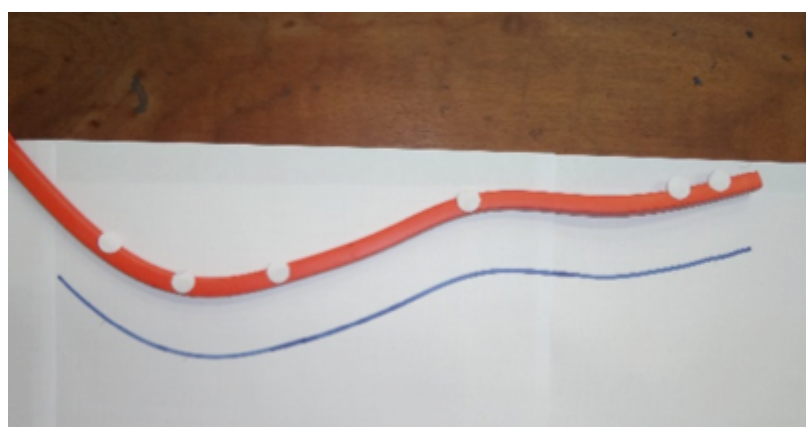

(b)

Figure 2 - Flexicurve outline on the paper in the flexion (a) and extension (b) position. 
3D videogrammetry assessment

The BTS Smart-DX system (BTS Bioengineering, USA), consisting of ten infrared cameras, with a sampling frequency of $25 \mathrm{~Hz}$ and reflexive markers (diameter $=12 \mathrm{~mm}$ ) was used. The system was calibrated according to the manufacturer's instructions, with an error of less than $0.5 \mathrm{~mm}$ within the volume calibrated.

The anatomical reference points on the SPs of vertebra C7, T1, T2, T4, T6, T8, T10, T12, L2, L4 and S2 were palpated and the markers attached with double-sided tape. Videogrammetry assessments were conducted with the spine in the neutral and maximum flexion and extension positions.

Data analysis - angular measurements

A routine developed in MATLAB ${ }^{\circledR} 8.5$ specifically for this study enabled to calculate the ROM in the maximum flexion and extension positions with both methods (Flexicurve and videogrammetry).

Based on the anatomical reference points, the spine was represented by a $3^{\text {rd }}$ order polynomial for the thoracic spine and another for the lumbar spine. Angulation between the lines tangential to the SPs of T1 and T2, for the thoracic region, and T2 and S2, for the lumbar region, defined the following angles: maximum flexion, extension and neutral spine positions. The ROM of each situation (flexion and extension) was defined as the difference between the maximum angles and neutral position angle. ROM values for the lumbar region represent the inversion of the physiological curve during maximum flexion.

\section{Statistical Analysis}

Statistical analysis was conducted using the Statistical Package for the Social Sciences (SPSS) program, version 20. The Shapiro-Wilk test was applied to confirm data normality. In addition, the following tests were used: (1) Pearson's ProductMoment Correlation coefficient [21]; (2) RMS error [21]; and (3) the Bland-Altman plot [22]. The correlation was classified as insignificant (between 0 and .30), low (between .30 and .50), moderate (between .50 and .70), high (between .70 and .90) and very high (between .90 and 1.00) [23]. Significance was set at 0.05 in all tests.

\section{Results}

The ROM values for flexion and extension for both the thoracic and lumbar region were equal to the average between the two instruments, with high correlations for thoracic flexion, thoracic extension and lumbar flexion, and RMS errors less than $8^{\circ}$. For lumbar extension, the correlation was moderate, with RMS error of more than $10^{\circ}$ (Table 1 ).

Table 1 - Mean, standard deviation, minimum and maximum range of motion (ROM) in flexion and extension, calculated for the thoracic and lumbar region

\begin{tabular}{|c|c|c|c|c|}
\hline ROM & Videogrammetry & Flexicurve & $r$ & RMS error \\
\hline Thoracic Flexion & $\begin{array}{c}77.2^{\circ} \pm 7.7^{\circ} \\
\left(53.9^{\circ}-89.9^{\circ}\right)\end{array}$ & $\begin{array}{c}77.2^{\circ} \pm 5.8^{\circ} \\
\left(63.1^{\circ}-90.3^{\circ}\right)\end{array}$ & $\begin{array}{c}0.751 \\
(p<0.00)\end{array}$ & $5.0^{\circ}$ \\
\hline Lumbar Flexion & $\begin{array}{l}-16.3^{\circ} \pm 10.4^{\circ} \\
\left(-32.3^{\circ}-13.2^{\circ}\right)\end{array}$ & $\begin{array}{l}-16.3^{\circ} \pm 8.9^{\circ} \\
\left(-31.8^{\circ}-8.2^{\circ}\right)\end{array}$ & $\begin{array}{c}0.853 \\
(p<0.01)\end{array}$ & $5.4^{\circ}$ \\
\hline Thoracic Extension & $\begin{array}{l}31.7^{\circ} \pm 13.4^{\circ} \\
\left(2.5^{\circ}-54.0^{\circ}\right)\end{array}$ & $\begin{array}{l}31.7^{\circ} \pm 10.9^{\circ} \\
\left(8.9^{\circ}-50.0^{\circ}\right)\end{array}$ & $\begin{array}{c}0.814 \\
(p<0.01)\end{array}$ & $7.7^{\circ}$ \\
\hline Lumbar Extension & $\begin{array}{l}47.7^{\circ} \pm 13.6^{\circ} \\
\left(20.3^{\circ}-74.2^{\circ}\right)\end{array}$ & $\begin{array}{c}47.7^{\circ} \pm 8.4^{\circ} \\
\left(28.6^{\circ}-71.5^{\circ}\right)\end{array}$ & $\begin{array}{c}0.613 \\
(p<0.01)\end{array}$ & $10.6^{\circ}$ \\
\hline
\end{tabular}

Note: r: Pearson's product-moment coefficient; RMS error: square root of the average of the quadratic difference between the values obtained in each method.

Graphic analysis of Bland-Altman revealed lower limits of agreement between the methods for flexion $\left( \pm 10^{\circ}\right)$ than for extension, for both the thoracic and lumbar regions 


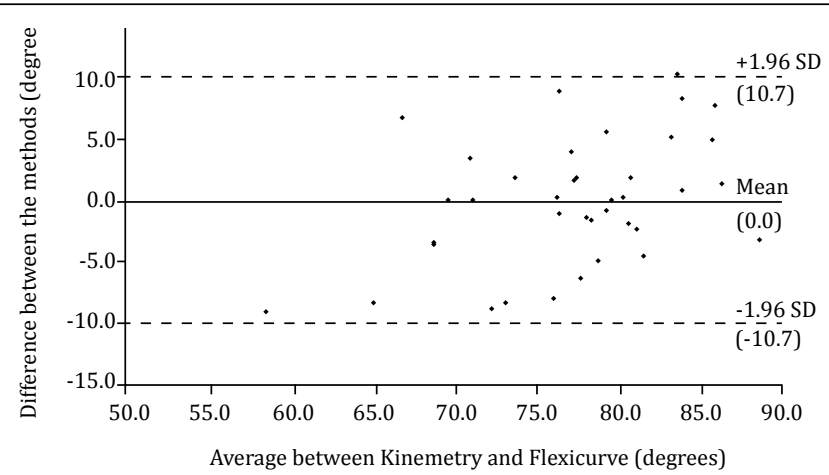

(a)

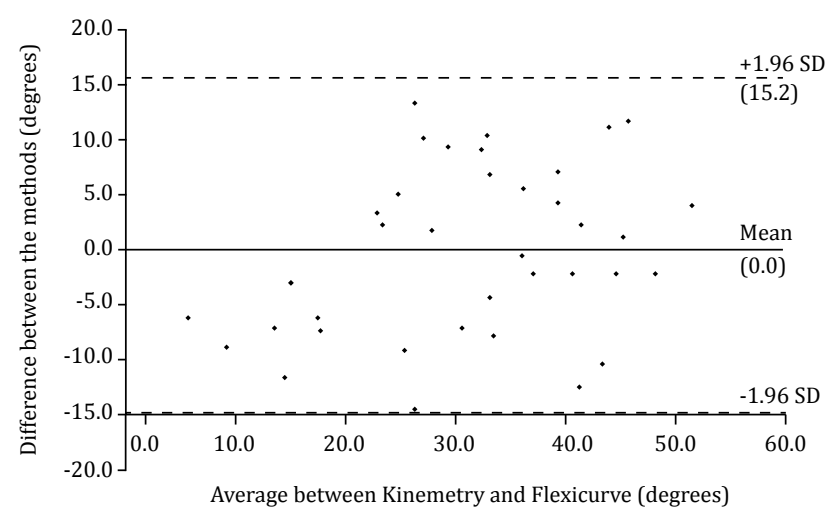

(c)

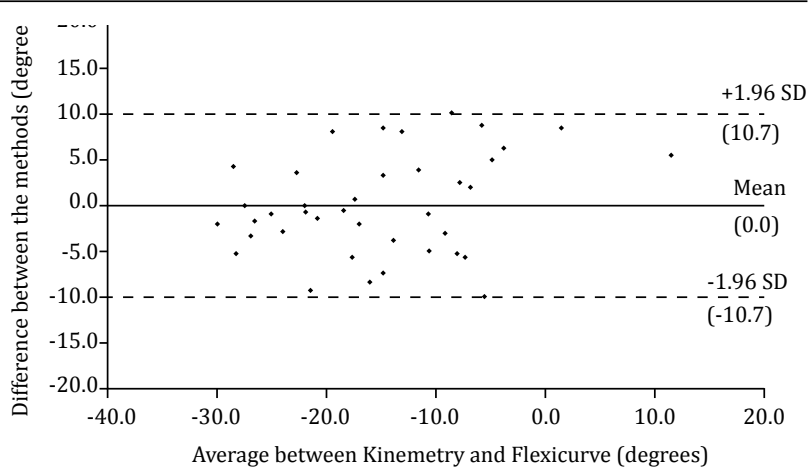

(b)

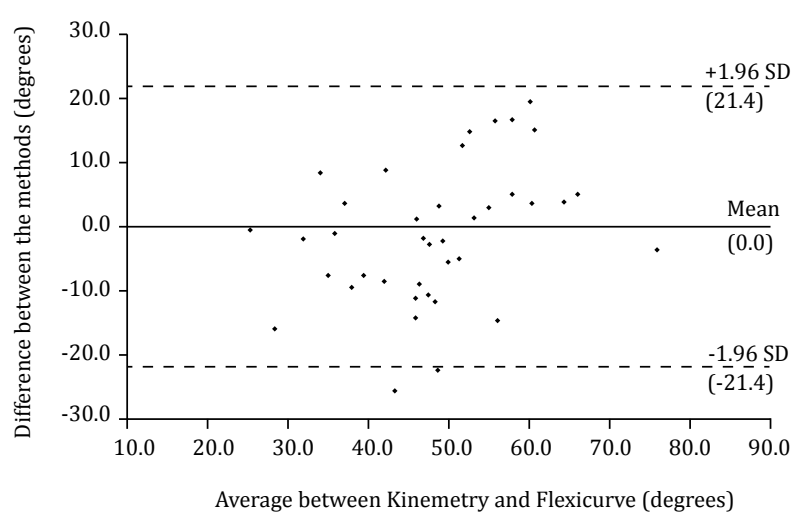

(d)

Note: The points represent the measurements of each instrument obtained by the two methods, where the differences between the values ( $y$-axis) are plotted as a function of the respective averages of the values obtained by the two instruments ( $\mathrm{x}$-axis).

Figure 3 - Bland-Altman Analysis: (a) thoracic flexion, (b) lumbar flexion, (c) thoracic extension, and (d) lumbar extension.

\section{Discussion}

Pearson's correlation was used to assess the degree of association between the measures. This technique expresses an index of the linear association between two continuous variables and has been represented as a usual measure of validity. However, it cannot determine systematic differences and is highly sensitive to the range and extreme values of the variable analyzed [24]. Thus, in a group with varied characteristics (e.g., large inter-subject variability), Pearson's correlation could overestimate the association and draw erroneous conclusions in terms of instrument validity [25]. For this reason, it has been recommended that the difference between methods be assessed.

The RMS error expresses the absolute differences between the methods. In thist study, RMS errors varied from $5^{\circ}$ to $10.6^{\circ}$ (Table 1 ). It is important to underscore that when assessed from a percentage standpoint (RMS error divided by the respective
ROM), the errors are relatively smaller when the region is assessed in the physiological direction of the curvature. In the thoracic region, for example, flexion has an error of $6.5 \%$ (RMS error of $5.0^{\circ}$ in $77.2^{\circ}$ of ROM), and extension, an error of $24.3 \%$ (RMS error of $7^{7} 7^{\circ}$ in $31.7^{\circ}$ of ROM). The same occurred for lumbar curvature, where the errors were relatively small during extension. The method proposed by Bland-Altman [22, 26, 27] also assesses the difference between the methods. The systematic error can be seen on the y-axis, by the average difference between the methods. In this study, the average difference between the methods was close to zero in all the analyses, indicating no systematic error.

The scattering of points on the Bland-Altman plot provides information on the random error. It is important to underscore that the limits of agreement of the Bland-Altman method are equal to approximately two RMS errors more or less than the average difference between the methods [28, 29]. In 
our study, the highest limits of agreement occurred in lumbar extension $\left( \pm 21^{\circ}\right)$, indicating low agreement between the Flexicurve and videogrammetry and suggesting that caution should be taken when using the Flexicurve to measure the ROM of maximum lumbar extension.

Few studies have validated methods that assess spinal flexibility. Schuit et al. [30] validated 3D videogrammetry (OSI SMA) to quantify lumbar flexion and extension in relation to X-ray examinations $(\mathrm{n}=10)$. The authors found a low correlation index for extension $(r=0.39)$ and none for flexion $(r=0.1)$ and Bland-Altman analysis found limits of agreement varying between $\pm 14^{\circ}$ and $\pm 22^{\circ}$. Nevertheless, the authors concluded that, despite the random error in the confidence intervals, 3D videogrammetry agreed with the $\mathrm{x}$-ray examination.

Tillotson and Burton [18] determined the concurrent validity of the Flexicurve compared to $\mathrm{X}$-ray examination for lumber flexion and extension. Their results showed very high correlation values $(r=0.98)$ and average differences of zero and $-0.5^{\circ}$ for lumbar flexion and extension, respectively, with limits of agreement varying between $\pm 6^{\circ}$ for flexion $\pm 5^{\circ}$ for lumbar extension. These results indicate the agreement between the Flexicurve and the $\mathrm{X}$-ray examination, and are more promising than in our study, given that lower limits of agreement mean smaller errors between the measures. The difference between the findings of our study and those of Tillotson and Burton [18] may be related to the reference selected. While Tillotson and Burton [18] used X-rays, we used 3D videogrammetry, a technique several authors deem the gold standard for measuring maximum ROM [13-15]. It is important that the Tillotson and Burton [18] data used to validate the X-ray method be those of a single individual. Another aspect that should be considered is that in this study the Flexicurve and 3D videogrammetry were not simultaneously assessed. That is, we cannot guarantee that the participants performed the movements exactly the same way in each of the methods evaluated.

A study limitation is the lack of simultaneous assessment, since those with the Flexicurve occurred before videogrammetry was evaluated. It is important to highlight that flexibility is a complex variable that tends to increase with a rise in movements. It is also important to point out that the maximum range of each participant was self-reported, that is, we cannot confirm that all individuals performed the movement to its maximum range. Another limitation is associated with the data collection method selected, since only the last of the three repetitions performed was used to record the maximum angulation. At videogrammetry assessment, which occurred after its Flexicurve counterpart, maximum angulation was recorded at the sixth repetition, which may have affected the values obtained.

\section{Conclusion}

The Flexicurve proved to be valid in assessing maximum flexion and extension of the thoracic spine and maximum flexion of the lumbar spine. We suggest caution when assessing maximum extension of the lumbar spine.

\section{References}

1. Behnke R. Anatomia do movimento. Porto Alegre: Artmed; 2014.

2. Kuo Y, Tully EA, Galea MP. Video analysis of sagittal spinal posture in healthy young and older adults. J Manipulative Physiol Ther. 2009;32(3):210-5.

3. Coelho JJ, Graciosa MD, Medeiros DL, Pacheco SCSP, Costa LMR, Ries LGK. Influência da flexibilidade e sexo na postura de escolares. Rev Paul Pediatr. 2014;32(3):223-8.

4. Braccialli LMP, Vilarta R. Aspectos a serem considerados na elaboração de programas de prevenção e orientação de problemas posturais Rev Paul Educ Fis. 2000;14(2):159-71.

5. Alter MJ. Ciência da flexibilidade. Porto Alegre: Artmed; 2010.

6. Sahin N, Albayrak I, Durmus B, Ugurlu H. Effectiveness of back school for treatment of pain and functional disability in patients with chronic low back pain: a randomized controlled trial. J Rehabil Med. 2011;43(3):224-9. 
7. Gordon R, Bloxham S. A systematic review of the effects of exercise and physical activity on non-specific chronic low back pain. Healthcare. 2016;4(2):22.

8. Searle A, Spink M, Ho A, Chuter V. Exercise interventions for the treatment of chronic low back pain: a systematic review and meta-analysis of randomised controlled trials. Clin Rehabil. 2015;29(12):1155-67.

9. Delitto A, George SZ, Van Dillen L, Whitman JM, Sowa G, Shekelle P, et al. Low back pain: clinical practice guidelines linked to the International Classification of Functioning, Disability, and Health from the orthopaedic section of the American Physical Therapy Association. J Orthop Sports Phys Ther. 2012;42(4):A1-57.

10. Medeiros RB, Daros KAC. Avaliação das doses de radiação $\mathrm{X}$ recebidas por pacientes em estudos radiológicos. Radiol Bras. 1997;30(5):263-5.

11. Knott P, Pappo E, Cameron M, deMauroy JC, Rivard C, Kotwicki T, et al. SOSORT 2012 consensus paper: reducing x-ray exposure in pediatric patients with scoliosis. Scoliosis. 2014;9:4.

12. Valle MB, Schmit EFD, Sedrez JA, Candotti CT. Avaliação da amplitude de movimento da coluna torácica e lombar: Revisão sistemática com metanálise. J Phys Educ. 2018;29(1):e2946.

13. Zatsiorsky VM. Kinematics of human motion. Champaign: Human Kinetics; 1998.

14. Winter DA. Biomechanics and motor control of human movement. 4th ed. New Jersey: John Wiley \& Sons; 2009.

15. Vaughan CL, Davis BL, O'Connor JC. Dynamics of human gait. Cape Town: Kiboho Publishers; 1992.

16. Leardini A, Biagi F, Merlo A, Belvedere C, Benedetti MG. Multi-segment trunk kinematics during locomotion and elementary exercises. Clin Biomech. 2011;26(6):562-71.

17. Burton AK. Regional lumbar sagittal mobility: measurement by flexicurves. Clin Biomech. 1986;1(1):20-6.
18. Tillotson KM, Burton AK. Noninvasive measurement of lumbar sagittal mobility an assessment of the flexicurve technique. Spine. 1991;16(1):29-33.

19. Walter SD, Eliasziw M, Donner A. Sample size and optimal designs for reliability studies. Stat Med. 1998;17(1):101-10.

20. Oliveira TS, Candotti CT, La Torre M, Pelinson PPT, Furlanetto TS, Kutchak FM, et al. Validity and reproducibility of the measurements obtained using the Flexicurve instrument to evaluate the angles of thoracic and lumbar curvatures of the spine in the sagittal plane. Rehabil Res Pract. 2012:186156.

21. Field A. Descobrindo a estatística usando o SPSS. Porto Alegre: Artmed; 2009.

22. Bland JM, Altman DG. Statistical methods for assessing agreement between two methods of clinical measurement. The Lancet. 1986;1(8476):307-10.

23. Mukaka MM. A guide to appropriate use of correlation coefficient in medical research. Malawi Med J. 2012;24(3):69-71.

24. Bates BT, Zhang S, Dufek JS, Chen FC. The effects of sample size and variability on the correlation coefficient. Med Sci Sports Exerc. 1996;28(3):386-91.

25. Atkinson G, Nevill AM. Statistical methods for assessing measurement error (reliability) in variables relevant to sports medicine. Sports Med. 1998;26(4):217-38.

26. Altman DG, Bland JM. Measurement in medicine: the analysis of method comparison studies. The Statistician. 1983;32:307-17.

27. Bland JM, Altman DG. Measuring agreement in method comparison studies. Stat Methods Med Res. 1999;8(2):135-60.

28. Giavarina D. Understanding Bland Altman analysis. Biochem Med. 2015;25(2):141-51.

29. Hirakata VN, Camey SA. Análise de concordância entre métodos de Bland-Altman. Rev HCPA. 2009;29(3):261-8. 
30. Schuit D, Petersen C, Johnson R, Levine P, Knecht $\mathrm{H}$, Goldberg D. Validity and reliability of measures obtained from the OSI CA-6000 Spine Motion Analyzer for lumbar spinal motion. Man Ther. 1997;2(4):206-15.
Received in 01/26/2019

Recebido em 26/01/2019

Recibido en 26/01/2019

Approved in 11/08/2019

Aprovado em 08/11/2019

Aprobado en 08/11/2019 